\title{
The technical production, storage and conservation routes of chilli peppers (Capsicum spp.) produced in Benin and constraints impeding the development of the sector.
}

Nicéphore M. Glodjinon ${ }^{1}$, Pacôme A. Noumavo ${ }^{1,}{ }^{2}$, Kifouli Adéoti $^{1}$, Kamal Garba ${ }^{1}$, Sonangnon H. S. Kouhoundé ${ }^{1}$, Brice M. Ohin ${ }^{1}$, Hama Cisse ${ }^{3}$, Noel S. Tovide ${ }^{1}$, Marcellin C. Fainou$^{1}$, Fatiou Toukourou', Lamine Baba-Moussa ${ }^{2}$, Aly Savadogo ${ }^{3}$, Farid Baba-Moussa ${ }^{* 1}$. ${ }^{1}$ Laboratoire de Microbiologie et des Technologies Alimentaires, Faculté des Sciences et Techniques, Université d'Abomey-Calavi, 04 BP: 1107 Cotonou, République du Bénin.

${ }^{2}$ Laboratoire de Biologie et de Typage Moléculaire en Microbiologie, Faculté des Sciences et Techniques, Université d'Abomey-Calavi, 05 BP: 1604, Cotonou, République du Bénin.

${ }^{3}$ Laboratoire de Biochimie et Immunologie Appliquée, Unité de Formation et de Recherche en Sciences de la Vie et de la Terre, Université Professeur Joseph Ki-Zerbo, 03 BP : 7021, Ouagadougou 03, Burkina Faso. Corresponding author: Farid BABA-MOUSSA, +229 96926828, fbmouss@yahoo.fr

Key words: Chilli pepper, technical itineraries, constraints, mold.

Publication date 31/12/2019, http://www.m.elewa.org/JAPS

$1 \quad$ ABSTRACT

Chilli pepper (Capsicum spp.) is an annual vegetable fruit used as a spice in almost all food and especially in all local dishes in Benin. However, it is neglected in many countries and relegated to the background which does not favor the agricultural development. As a result, its cultivation and conservation are still traditional and face many cultural and post-harvest constraints. The objective of this work is to make an investigation on the current state of the chilli pepper sector in Benin from the planting, growth, harvest until the transformation through storage and preservation. Overall, the review presents all the technical shortcomings hindering the opening of the sector on its socio-economic environment and to make recommendations for the improvement of the quality of chilli pepper sold and consumed in Benin. Thus, the results of this review indicate that there are several local varieties of chilli pepper grown in Benin belonging to three species of the Solanaceae family: Capsicum chinense (annual variety), Capsicum annuum L. (annual variety) and Capsicum frutescens (perennial variety). Its production is generally in rainfed or irrigated crops, in truck farming or on mainland. The best farming technique is the one that begins with the nursery and its success depends on the quality of the plants resulting from this stage. The best methods of storage and preservation vouching a good sanitary quality of chilli pepper are still to be promoted. The main problem encountered by the tillage of chilli peppers in Benin is its contamination by mold during its production and storage. It is therefore important to follow the technical production, storage and preservation routes, to assess the susceptibility of chilli pepper to mold at each stage and to measure the mycotoxins throughout the production chain so as to vouch the safety of chilli pepper consumers and to develop the chilli pepper sector in Benin. 


\section{INTRODUCTION}

Chilli pepper (Capsicum spp.) is the second market gardening crop after tomatoes in Benin (INRAB, 2009). It is not only rich in vitamins $\mathrm{A}, \mathrm{B} 6, \mathrm{C}, \mathrm{E}, \mathrm{K}$, in trace elements such as copper, iron, manganese and potassium, but also in ascorbic acid, flavonoids, oligosaccharides and carotenoid compounds (Orobiyi, 2015). Chilli pepper is among the first spices or food additives in the world. It is one of the most produced and consumed vegetable crops and undeniably occupies a place of choice in Beninese households. Several varieties of chilli pepper are used as fresh fruit directly from the fields; in dried fruit from the conservation and processed into paste or powder for the different foods cooking. In addition to food, chilli pepper is also used for its medicinal properties (FAO, 2016). In phytomedicine, the fruit is used orally as an infusion to improve blood circulation, treat nausea, high blood pressure, diabetes and overweight (Lejeune et al., 2003; Koffi and al. 2014). Its frequent use in the treatment of various diseases in a traditional environment may be justified by the fact that its extracts possess antimicrobial properties (Koffi et al., 2014). Indeed, the main interest of chilli pepper is in its physico-chemical composition (Tilahun et al., 2013). Its high antioxidant content, including capsaicin, gives it a high nutraceutical value (nutritional and medicinal). But this physicochemical composition varies according to the varieties and the environmental conditions (Bae et al., 2012). In Benin, farmers grow chilli pepper for the household food supply and generate income. The production and trade of this speculation contribute to improving the stability of the food system and increasing the predictability of the source of income of potential producers and actors who export it (INRAB, 2009). The importance of this sector militated in favor of its inclusion in the Strategic Plan for Agricultural Sector Recovery (UNDP-BENIN-PANA 1， 2015). Chilli peppers are integrated into farmers' production systems in most parts of Benin. Despite the economic importance of chilli pepper, it remains very little studied by Beninese researchers. The few research projects carried out concern cultural practices, varietal improvement and agro-morphological characterization (INRAB, 2009; Orobiyi, 2015). The objective of this work is to draw up an inventory of the technical production routes, the methods of storing and preserving chilli peppers in Benin. A final chapter presents the main constraints to be raised in the chilli pepper sector in order to promote technical farming itineraries, standardized storage and conservation methods allowing a good sanitary quality of chilli pepper and the minimization of post-harvest losses caused by contaminants in the production chain so as to better this sector.

\section{GENERALITY ON THE CHILLI PEPPER}

3.1 Systematic and cultivated chilli al., 2006). Chilli pepper is grown throughout pepper varieties: The chilli pepper belongs to the genus Capsicum, the Solanaceae family, the Solanales order, the Magnoliopsida class or Dicotyledonous and the Magnoliophyta branch (Akouègninou et al., 2006). The genus Capsicum contains 27 species (ChaineDogimont, 1993) of which only 5 are domesticated worldwide (Costa et al., 2009; Brown et al., 2013). These are C. annuum, C. chinense, $C$. frutescens, and $C$. baccatum $L$. and $C$. pubescens. Only $C$. annum, $C$. chinense and $C$. frutescens are cultivated in Benin, (Akoègninou et

Benin and mainly in the 6 southern departments that provide $70 \%$ of the national production (UNDP-BENIN-PANA 1, 2015). It is produced in home gardens, agricultural development areas, in pure culture or in combination with other crops such as tomato (Solanum bycopersicum), corn (Zea mays), groundnut (Arachis bypogaea), cowpea (Vigna unguiculata subsp. Unguiculata), soybean (Glycine max), cassava (Manihot esculenta), and yam (Dioscorea dumetorum). The production is made in rainfed, irrigated or off-season crops. Several 
varieties of chilli pepper including small chilli peppers ("Salmon" and "Chilli pepper" or "Pilipili"), large chilli peppers ("Gbotakin" or "Safi" and "Gros de Dalao"), medium chilli peppers ("Sucette de Provence" and "Jaune du BurkinaFaso") and the long chilli pepper "Cayenne" known as Glazoue or Nigeria chilli pepper, are grown in Benin. These varieties belong to the three species of the Solanaceae family: Capsicum Chinense (annual and conical variety), Capsicum annuum L. (annual and long variety) and Capsicum frutescens (perennial and very small variety). 3.2 Chilli pepper production 3.2.1. In the World: The consumption of chilli peppers fruits (Capsicum spp.), probably ranked among the first spices or food additives is constantly increasing worldwide. In recent years, world chilli pepper production has steadily increased from 10769000 tons in 1991 to 22168000 tons in 2002 (FAO, 2003), doubling in size within a decade. Too, the world production of chilli peppers was evaluated in 2012 by FAO to more than 31 million tons (FAO, 2014). FAO statistics estimate the global chilli pepper production at 38,415,621 tonnes in 2016 in cultivated territory of $3,737,635$ ha (FAO, 2018). Several varieties are cultivated around the world. India is the largest producer of chilli peppers in the world that contribute $25 \%$ of the world's production. The Photo 1 below shows some chilli pepper varieties grown around the world.

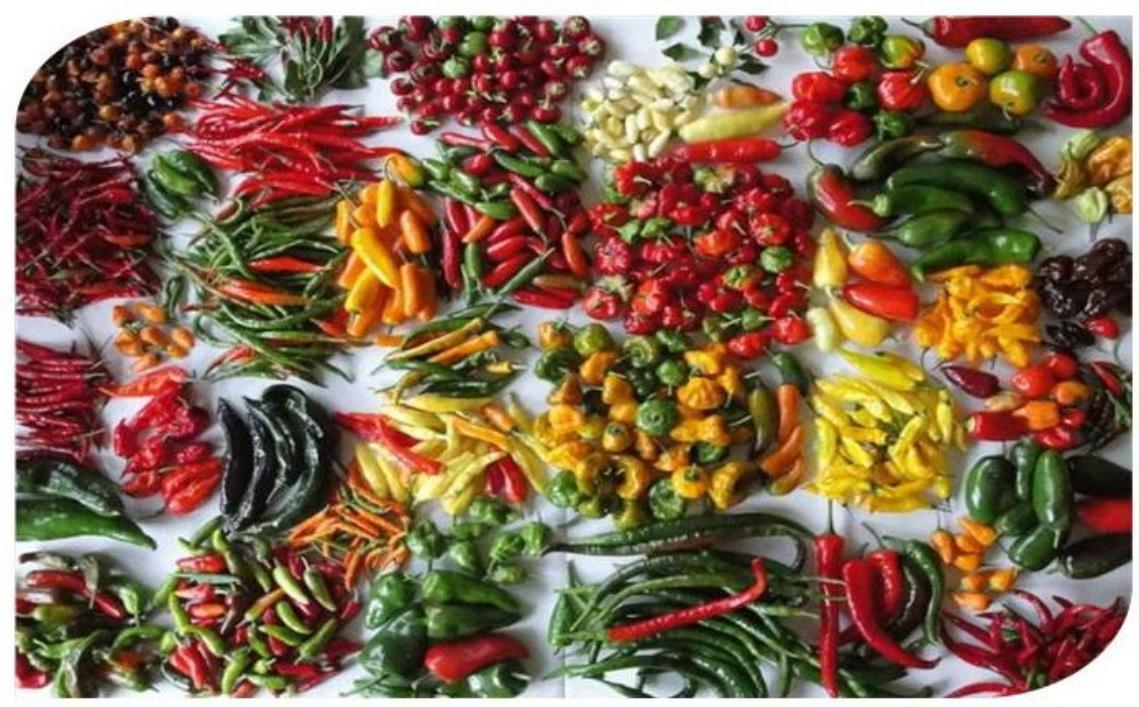

Photo 1: Chilli varieties grown around the world (Shankar et al., 2014)

3.2.2 In West Africa: In Africa, Nigeria, Egypt and Ghana have a regular production found on the international market (FAO, 2006). West Africa alone produces 1,703,612 tons for an area of 290,574 ha (or 4,435\% of world production). The largest producers in West Africa are Nigeria and Ghana, respectively ranked eighth and thirteenth in the world (FAO, 2016). The vast majority of chilli peppers produced in Africa are sold in local, regional (Senegal, Gambia, Liberia, Sierra Leone and Mali) and international markets
(Europe and North America). In Benin, there are several varieties that are cultivated throughout the national territory according to different farming techniques with cultivation methods more or less varied in market gardening as on the mainland. Benin ranks the 58th place on the world scale with a very low production that has been going up and down since 2000 until today.

3.2.3 In Benin: In Benin, the whole production in 2016 amounts to 176,536 tons (FAO, 2018) and still increases to this day. This 
expansion is justified by the use of chilli pepper as an ingredient in the cooking of many food dishes and shows the chilli pepper as a strategic market gardening product for Benin. Despite this weakness and instability in annual production, Benin is one of the major producers of West Africa before countries like Niger, Burkina Faso, Mali, Côte d'Ivoire and Togo (FAO, 2016). In addition, in Benin, the price of a chilli pepper bag (bag containing 100 $\mathrm{kg}$ of maize) can raise up from 10,000 CFA francs during the period of abundance to 45,000 CFA francs in the shortage period
(Orobiyi, 2015). Chilli pepper cultivation is therefore an important source of income for producing households. Women are the main processors, traders and users of kitchens in Africa and benefit from the potential income of chilli pepper production. Chilli pepper culture therefore plays an important role in reducing poverty in developing countries.

3.3 Characteristics of chilli pepper grown: Several species of Chilli peper are produced. The Table 1 presents the characteristics of the main species of chilli pepper grown in the the world.

Table 1 : Main characteristics of chilli pepper species grown in the world (INRAB, 2009)

\begin{tabular}{|c|c|}
\hline Chilli pepper species & Principal Characteristics \\
\hline $\begin{array}{l}\text { Capsicumchinense } \\
\text { Jacq. }\end{array}$ & $\begin{array}{l}\text { Its fruits ( } 2 \text { to } 6 \text { per knot) are of various shapes, in lanterns, or very flat ribs, very pungent (up to } 250,000 \text { on the scale of Scoville) to } \\
\text { sweet and very fragrant. The species is also renowned for its long harvest period, its almost zero pesticide requirements and its very } \\
\text { significant cost of production. Its cycle varies between } 80 \text { and } 120 \text { days on average. Seeds are slow to germinate. The species is } \\
\text { very popular in the rainy season for its vigor and its great resistance to anthracnose and virus diseases (Grubben et El Tahir, 2004). }\end{array}$ \\
\hline $\begin{array}{l}\text { Capsicum } \\
\text { frutescens } L \text {. }\end{array}$ & $\begin{array}{l}\text { Perennial species whose height of the plants depends on the climate, with fine foliage, flowers often in clusters inserted in pairs. } \\
\text { The leaves are sometimes ovoid. The floral peduncle is right to flowering and the fruits are elongated conical (sometimes round), } \\
\text { very pungent but scented little. They are easy to dry (Williams et al., 1991; De Witt et Bosland, 1993). }\end{array}$ \\
\hline $\begin{array}{l}\text { Capsicum } \\
\text { annuumL. }\end{array}$ & $\begin{array}{l}\text { Annual species as the name suggests. } \\
\text { In this species we usually find varieties with sweet fruits but also some varieties with pungent fruits (Messiaen, } 1975 \text {; Greenleaf, } \\
\text { 1986). }\end{array}$ \\
\hline Capsicum & Characterized by its very hairy ovoid leaves (hence its name) and its blue flowers, its black and irregular seeds. \\
\hline $\begin{array}{l}\text { pubescens Ruiz et } \\
\text { Pav. }\end{array}$ & $\begin{array}{l}\text { The species is characteristic of high areas. Large perennial bush that can grow up to } 3 \mathrm{~m} \text { high. Its growth cycle is at least } 120 \text { days. } \\
\text { Its fruits are dehydrated and do not keep well (Eshbaugh, } 1977 \text {; Chaine- Dogimont, 1993). }\end{array}$ \\
\hline $\begin{array}{l}\text { Capsicum } \\
\text { baccatum L. }\end{array}$ & $\begin{array}{l}\text { Species distinguished by its white corolla marked yellow herringbone and stamens free. It is mainly used as a condiment. It is } \\
\text { characteristic of the Andes, zone in which one also meets its wild form. Its cycle is about } 120 \text { days and the plants of C. baccatum } \\
\text { have because of their persistence, a shrub tendency. There are two wild forms in this group (baccatum and microcarpum) and a } \\
\text { domesticated form (pendulum) (Pickersgill, } 1971 \text {; De Witt et Bosland, } 1993 \text {; Chaine-Dogimont, 1993). }\end{array}$ \\
\hline
\end{tabular}

\subsection{Vernacular catalogue and} morphological features of chilli peppers recognition grown in Benin: The vernacular names of varieties registered in Benin vary from one village to another and from one ethnic area to another. Each village seems to have its own set of names. These observations, common in vernacular nomenclature, have already been reported in many crops such as fonio (Digitaria exilis)(Adoukonou-Sagbadja et al., 2006), traditional leafy vegetables (Adjatin et al., 2012), cassava (Manihot esculenta) (Kombo et al., 2012), cowpea (Vigna unguiculata subsp. Unguiculata) (Gbaguidi et al., 2013), the earth lens (Macrotyloma geocarpum) (Assogba et al., 2015) and sorghum (Sorghum bicolor) (Dossou Aminon et al., 2015). Agro-morphological and molecular characterizations will clarify this problem of synonymy as indicated by Assogba and al. (2015) and Gbaguidi and al. (2015). According to Akoègninou and al. (2006), it is through the shape and size of the fruits that producers recognize the varieties of chilli pepper species they grow. These producers' knowledge on chilli pepper can be capitalized by taxonomists and geneticists as recommended by Dansi and al. (2010) on fonio, Gbaguidi and al. (2013) on cowpea and Kombo and al. (2012) on cassava. According to Orobiyi (2015), the three species of chilli pepper are widespread in Benin and 
have been particularly observed in cultivation in almost all villages in southern, central and northern Benin. In fact, the characteristics of chilli peppers grown in Benin vary from one production area to another (Table 2). Cultivars or local varieties of the species $C$. chinense (Gbotakin in the local language) are very much loved by consumers (Photo 2). The local varieties of the $C$. annum species (Takingaga or Afundja in local language) (Photo 3) and those of the species C. frutescens (Danhometakin in local language) (Photo 4) are in their case very adapted to drying and as such, their postharvest conservation for domestic use or sale at high cost during off-season is relatively easy. Of the two species with good technological conservation qualities, the species $C$. frutescens (Danhometakin) is uncommon and this is due to its very low productivity, unprofitable production and extremely pungent taste.

Table 2: Characteristics of different chilli pepper varieties grown in Benin and their production areas (INRAB, 2009)

\begin{tabular}{|c|c|c|c|c|c|c|c|}
\hline $\begin{array}{l}\text { Varieties } \\
\text { (in local language) }\end{array}$ & Origin & Characteristics & $\begin{array}{c}\text { Cycle } \\
\text { (month) }\end{array}$ & Culture period & Adapted region & $\begin{array}{l}\text { Susceptibility } \\
\text { to pests }\end{array}$ & Yield (t/ha) \\
\hline \multirow{2}{*}{$\begin{array}{l}\text { Gbotakin } \\
\text { Adologbo, Afundja, } \\
\text { Adjatakin }\end{array}$} & Local & $\begin{array}{l}\text { Small medium or big, } \\
\text { round, elongated, } \\
\text { perfumed or not, spicy } \\
\text { or not }\end{array}$ & 3 & July to March & $\begin{array}{l}\text { From south to } \\
\text { north }\end{array}$ & $\begin{array}{l}\text { Average } \\
\text { sensitivity }\end{array}$ & 7 to 10 \\
\hline & Local & Long, spicy & 3 to 4 & July to January & $\begin{array}{l}\text { From south to } \\
\text { north }\end{array}$ & Very sensitive & 3 to 5 \\
\hline Accra takin & & Medium to long, spicy & 3 & July to January & South & Sensitive & 3 to 7 \\
\hline Bird chilli (Pili-Pili) & Local & $\begin{array}{l}\text { Very small, conical } \\
\text { and verysharp }\end{array}$ & 3 to 4 & All year & Center & Tolerant & $<1$ \\
\hline Glazoue & Local & Long and conical & 3 & July to December & Center & $\begin{array}{l}\text { Average } \\
\text { sensitivity }\end{array}$ & 3 to 5 \\
\hline Elisee & $\begin{array}{l}\text { Old, introduced } \\
\text { from Ivory Coast }\end{array}$ & $\begin{array}{l}\text { Small conicalpepper, } \\
\text { spicy }\end{array}$ & 2 to 3 & July to December & Center & $\begin{array}{l}\text { Average } \\
\text { sensitivity }\end{array}$ & 1 to 2 \\
\hline $\begin{array}{l}\text { Tatasse (local } \\
\text { pepper) }\end{array}$ & Old introduced & $\begin{array}{l}\text { Very big and } \\
\text { elongatedsweet }\end{array}$ & 3 & July to December & North & Very sensitive & 10 to 15 \\
\hline $\begin{array}{l}\text { Safi, yellow from } \\
\text { Burkina }\end{array}$ & $\begin{array}{l}\text { Improve } \\
\text { introduced }\end{array}$ & $\begin{array}{l}\text { Big, round, very hot, } \\
\text { yellow to redwhen } \\
\text { ripe }\end{array}$ & 4 to 5 & July to December & North & Sensitive & 5 to 10 \\
\hline Salmon & $\begin{array}{l}\text { Improve } \\
\text { introduced }\end{array}$ & Small, spicy & 2 to 3 & July to October & $\begin{array}{l}\text { South, Center, } \\
\text { North }\end{array}$ & Sensitive & 3 to 5 \\
\hline
\end{tabular}
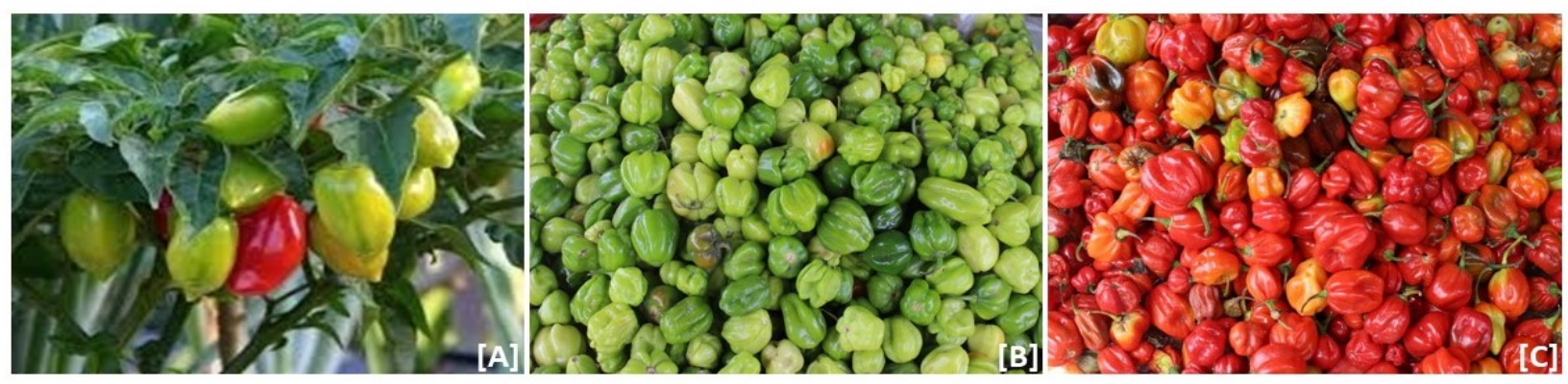

Photo 2: Species varieties of Capsicum chinense (Gbotakin in local language) [A] Gbotakin in the open field, [B] Gbotakin after harvest, [C] Gbotakin during storage. 

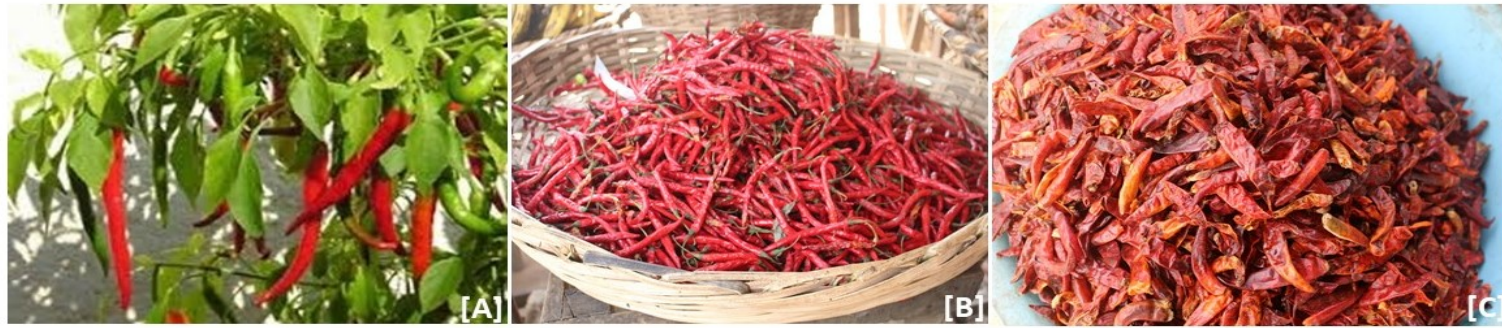

Photo 3: Species varieties of Capsicum annuum (Afundja in the local language) [A] Afundja in the open field, [B] Afundja after harvest, [C] Afundja after storage.
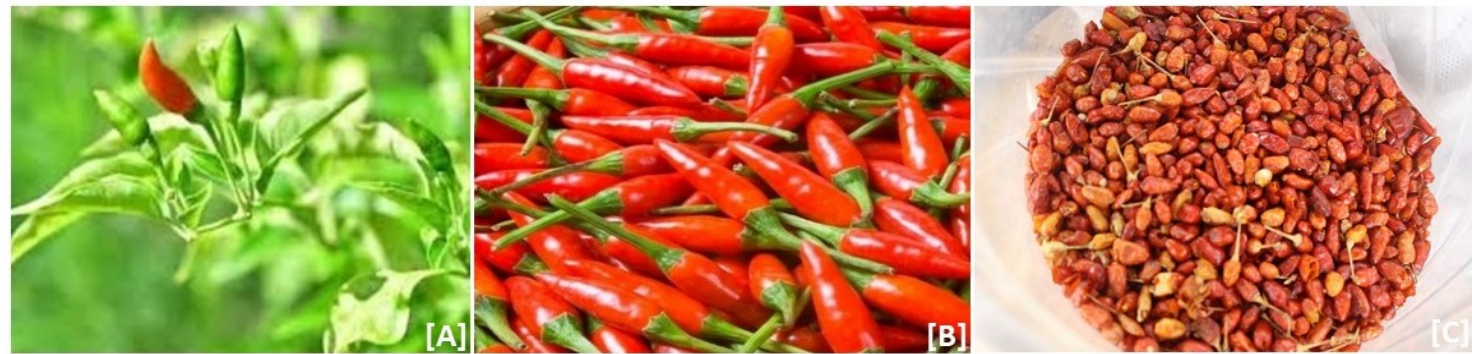

Photo 4: Species varieties of the Capsicumfrutescens (Danhometakin)

[A] Danhometakin in the open field, [B] Danhometakin after harvest, [C] Danhometakin after storage.

3.5 Chemical composition of chilli pepper: The chemical composition of chilli pepper varies considerably depending on the type of cultivar, ecological conditions, harvest stage and post-harvest conservation (dry or fresh green or red fruit) (Tilahun et al., 2013; Kumari et al., 2014). Thus, the approximate chemical composition for 100 grams of fresh chilli pepper is shown in Table 3. Chilli pepper also contains oleoresin which gives the chilli pepper its aromatic odour (Jin et al., 2009).
Drying results in a significant loss of carotene and thiamine and the disappearance of almost all vitamin C (Tilahun et al., 2013). Capsaicin is the compound that gives the chilli pepper a tangy taste (Tundis et al., 2013). It is an odourless, colourless and tasteless alkaloid complex that is concentrated in varying amounts (0.01 to $1.0 \%$ dry weight) in the placental tissue and pericarp of the fruit, but it is found in all fleshy parts of very pungent varieties (Tilahun et al., 2013).

Table 3: Approximate chemical composition of 100 grams of fresh chilli pepper (variety Capsicum chinense) (Jin et al., 2009)

\begin{tabular}{lcc}
\hline Composition & Units & Value (100 g) \\
\hline Water & $\mathrm{g}$ & 74 \\
Energy & $\mathrm{KJ}$ & 395 \\
Protein & $\mathrm{g}$ & 4,1 \\
Lipids & $\mathrm{g}$ & 2,3 \\
Carbohydrates & $\mathrm{g}$ & 18 \\
Fibers & $\mathrm{g}$ & 6 \\
Calcium & $\mathrm{mg}$ & 58 \\
Phosphorus & $\mathrm{mg}$ & 101 \\
Iron & $\mathrm{mg}$ & 2,9 \\
Carotene & $\mu \mathrm{g}$ & 7140 \\
Thiamin & $\mathrm{mg}$ & 0,25 \\
Riboflavin & $\mathrm{mg}$ & 0,2 \\
Niacin & $\mathrm{mg}$ & 2,4 \\
Ascorbic acid & $\mathrm{mg}$ & 121 \\
\hline
\end{tabular}


3.6 Uses of chilli pepper: Chilli peppers fruits are widely used in the diet. More than $40 \%$ of harvested chilli peppers are used in kitchens (Adetula and Olakojo, 2006). Indeed, chilli pepper fruits are eaten fresh, dried or processed. The most pungent forms, including the hot chilli pepper (Capsicum annum) and the bird chilli pepper (Capsicum frutescens), are consumed in very small quantities and considered as a spice for seasoning sauces and stimulating appetite. On the other hand, the less pungent forms (the West Indian chilli pepper) are used as a vegetable. However, there is no limit between the use of chilli pepper as a spice and as a vegetable (Grubben et Tahir, 2004). Chilli pepper is used in spice blends to give flavour to all kinds of dishes. Chilli pepper is an excellent source of vitamin $A$ and $C$ (Boland et Batavia, 2000). It is used in the industry as an ingredient in many products such as canned fish, ginger beer, and in some pharmaceuticals. Chilli pepper is widely used in traditional medicine. Hot chilli peppers cause a high salivation, participate in digestion and have a laxative effect. Capsaicin has antioxidant, antimutagenic, anticarcinogenic and immunosuppressive properties (Jin et al., 2009). The use of intravesical capsaicin has led to a better understanding of the pathophysiology of hyperparksis of paraplegic (Labat, 1996). Also, capsaicin has beneficial effects on energy metabolism and food intake in people who have lost weight (Guerrero, 2000). Hypocholesterolemic effects have been identified in oleoresin (Tilahun et al., 2013). Chilli pepper powder was found to be effective in reducing the intensity of dyspeptic symptoms in a clinical trial on 30 patients with functional dyspepsia (Bortolotti et al., 2002).

3.7 Varietal diversity, distribution and extent of chilli pepper in Benin: There is a great diversity in chilli pepper grown in Benin. This diversity could be explained by the fact that varietal introductions from the Republic of Togo and / or the flow of genes between different species of chilli pepper are high. It can also be explained by the mixtures of different species of chilli pepper in culture. According to producers, the low diversity observed in some villages in Oueme (southern Benin) is due to a concentration of production on a small number of highly productive and economically profitable varieties. In the other villages of this department, the low diversity observed can be explained by the cultivated chilli pepper groups which prevents cross-group crosses responsible for the appearance of new genotypes. The Shannon index to measure species diversity has shown that southern and central Benin have moderate varietal diversity, while the north has high diversity. However, pockets of high varietal diversity exist in the Center and South (based on the spatial analysis of diversity carried out by the kriging method) and are observed in the Couffo, Mono and Collines departments. These results can be explained by the introduction of new chilli pepper varieties from the Federal Republic of Nigeria and the Republic of Togo. Unfortunately, pockets of high diversity have not been observed in the North where varietal diversity is high (according to the Shannon index). This result could be explained by the fact that there is no large variation in the number of varieties grown per village. The regions of Oueme, Plateau and Mallanville recognized as chilli pepperproducing areas in Benin should show considerable varietal diversity or the existence of a pocket of strong diversity, (AssogbaKomlan et al., 2007). According to producers, the low diversity observed in some southern and northern regions of the country is also due to a concentration of production on a small number of highly productive and economically profitable varieties. The majority of the producers also cultivate the three groups of hot chilli peppers (small, long and round chilli peppers) reported in Benin by Akoègninou and al. (2006). This shows that the chilli pepper in each of these groups is of particular importance to producers and consumers, given the shelf life and the presence of aroma in their fruit. 


\section{TECHNICAL ITINERARY}

4.1 Cultivation technical itinerary of chilli pepper in Benin: There are usually four chilli pepper farming systems: rainfed crops, recession crops, lowland crops and irrigated crops. In Benin, the farm size averages is 1.13 ha per farmer with the smallest acreage being 0.06 ha and the largest being 4 ha. Field operations include: field preparation, nursery installation and management, plant placement, crop management, harvesting and packaging, product storage and storage. Producers (market gardeners or farmers) often work individually. But in areas of high production, particularly valleys and urban or peri-urban areas, there are peasant organizations (village groups). They are production or service cooperatives (INRAB, 2009). The analysis of the ripening time of the fruits showed that there is no relationship between the maturation period of the varieties and the type of chilli pepper ( $C$. annum, $C$. chinense and $C$. frutescens) grown. According to the producers, the chilli pepper maturation period is influenced by the soil moisture and fertility and the state of the sown seeds. With regard to soil fertilization, only a few producers use biological means such as organic bottom manures i.e. chicken droppings, cow dung, compost and peanut or cowpea fennel and Mucana leaves as green manure to increase the productivity of the chilli pepper they grow. The majority of producers produce chilli pepper with chemical fertilizers that have adverse environmental and health consequences for producers and consumers (Kumari et al., 2014). With regard to plant health protection, the means of integrated struggle are very little known by the producers. These means of struggle must be encouraged to protect not only crops against pests and pathogens, but also the environment and the health of populations for sustainable agriculture. It is also important to note that at the country level, women are more active in chilli pepper production than men. They intervene at each level of production. It is a culture that does not require much physical effort and allows women to meet their daily needs. The chilli pepper culture is done in four (4) stages, the most delicate of which is that of the nursery (INRAB, 2009). These different steps are summarized as follows:

a. The nursery: The chilli pepper production depends on the quality of the nursery stock; it is a delicate step and it is important to strictly follow the indications proposed in this document. Nursery time varies from 21 to 35 days depending on the variety, soil type, period and area of production.

b. Seed Supply: In traditional chilli pepper production, several varieties are grown simultaneously and the seeds come from the fruits taken from the previous harvest. This self-production of seeds is not recommended because it reduces the performance (yield, shape, colour.) of the variety thus multiplied.

c. Establishment of the nursery: The establishment of a nursery involves the succession of operations that are the delimitation of the area, the choice of the type of nursery, the preparation of the plot, fertilization of the soil, sowing and maintenance. The nursery is usually done on well calculated areas. The board intended for the nursery must be flat, sandy, well drained and rich in organic way. It must be installed in a sunny and ventilated area of the field, sheltered from the wind and as close as possible to a source of water to facilitate watering.

d. Transplanting and Care of the culture: This step consists in materializing the pockets on the plot to be transplanted with strings and stakes while avoiding the holes too deep of 3 to $4 \mathrm{~cm}$. Then select vigorous seedlings and tear them off with the clod around the roots. Thoroughly compact the soil around the roots without damaging the collar of the seedling and, if possible, irrigate immediately after transplanting. The maintenance of the culture consists of operations of sacro-hump, irrigation, phytosanitary protection and fertilization of the soil.

e. Harvest: Fruit harvesting normally begins 3 months after transplantation on 
several occasions (3-5 harvests) (Assogba et al., 2009; Hakmaoui et al., 2013). The fruit matures gradually taking a deep red colour (blood colour). Fruits on bright, sunny sides are the first to ripen compared to those in the shade and interior of the foliage. Partial dehydration of the fruits on the plants is recommended because the colour stability in the chilli pepper is better when the harvest is late. As maturity increases, the dry matter content increases along with the intensity of the colour. Harvesting should be early in the morning and should be avoided during or just after the rains (Hakmaoui et al., 2013).

4.2 Technical itineraries for drying, storage and conservation: For all agri-food crops, the management of post-harvest losses is very important. Generally, chilli pepper harvest is spread over a maximum of 3 to 5 months depending on the variety (Assogba et al., 2009; Hakmaoui et al., 2013). Fresh fruits harvested and dried fruits are packed in baskets, basins and bags. The chilli pepper dried and then ground is packaged in particular in small transparent bottles perforated lid or not. Wet or dry milling and drying are the forms of chilli pepper processing. Wet milling is done with stone grinders or small moving grinders. Dry milling is done with the grain mills. Natural drying in the sun is often the artisanal process used in Benin (UNDP-BENIN-PANA 1, 2015). There are improved natural drying techniques using solar dryers equipped with a solar energy capture device. With regard to drying, storage and storage techniques, the information provided by the producers shows that: (i) The variety "Gbotakin" of the species Capsicum Chinense is difficult to preserve; (ii) The other varieties of chilli peppers (Takingaga or Afundja) of the species Capsicum annum and (Danhometakin) of the species Capsicum frutescens are predisposed to drying. Among the different drying methods, we have:

a. Traditional solar drying: Natural sun drying is the process traditionally used by producers. It is usually done on the production site and consists of spreading, exposing to sunlight and wind and this for several days (8 to
10 days), and the fresh fruits of chilli pepper on the ground or on mats, racks, on the shoulder of paved roads or rooftops. To avoid rotting berries during solar drying, the fruits to be dried are first soaked in boiling water to destroy parasites and microorganisms and then drained into baskets. This drying process makes it possible to reduce the moisture content of the chilli pepper to between 14 and $12 \%$ in order to guarantee its preservation. It is simple and cheap (free energy); but it causes losses of vitamins and colour, and carries serious risks of contamination.

b. Improved solar drying: Improved natural drying techniques or drying by solar dryers (direct, indirect or mixed) overcomes the various disadvantages of traditional drying. The types of dryers available are traditional sunimproved drying using rail-mounted dryers, traditional shade-enhanced drying using sheltered dryers and improved drying using solar dryers.

c. Packaging: Dried fruits are stored in new or recycled polyethylene bags (used for rice for example) that can hold about $40 \mathrm{~kg}$. Dried fruits are sometimes turned into powder and stored for sale. There is no infrastructure development for post-harvest chilli peppers in Benin (Assogba et al., 2009; UNDP-BENINPANA 1, 2015). The forms of processing of chilli pepper are: milling and drying. We distinguish wet milling and dry milling. The products resulting from the processing of chilli pepper are: ground fresh chilli pepper, ground chilli pepper and whole dry chilli pepper. Wet milling is done in neighbourhoods and markets with stone grinders or small portable grinders. Dry milling is done in the grain mills. There is no doubt that the drying and storage methods used in Benin favor the contamination of preserved chilli peppers (Assogba et al., 2009; UNDP-BENIN-PANA 1, 2015). The drying must be done according to the required standards and hygienic: adapted drying areas and clean to guarantee the sanitary quality of the finished product. Dried fruits are stored in new or recycled jute or polyethylene bags that can hold about $40 \mathrm{~kg}$. These bags are kept in a 
cool, ventilated area away from sunlight and light (Assogba et al., 2009; Hakmaoui et al.,
2013; UNDP-BENIN-PANA 1, 2015).

\section{DISTRIBUTION, CONSUMPTION AND MARKETING OF CHILLI PEPPERS IN BENIN}

Chilli pepper is distributed nationally as whole fruit, fresh or dry, milled in a wet or dry state (Assogba et al., 2009; UNDP-BENIN-PANA 1, 2015). Its pungent flavour is very popular for seasoning almost any dish in Benin. Part of the chilli pepper is exported mainly in the dry state in West African countries. Chilli peppers are widely distributed in Benin because of their importance in the diet (Assogba et al., 2009). This distribution is the work of resellers from the main markets who have a close relationship with retailers. Merchants in consumer markets, retailers source from secondary markets or from wholesalers and redistribute them to consumers down the production chain in rural areas and cities of Benin. Packaging is the $50 \mathrm{~kg}$ to $65 \mathrm{~kg}$ basket for products resold in Benin cities and 80 to $100 \mathrm{~kg}$ for baskets going to

Nigeria, Niger and Togo. Foreign consumers in West Africa are mainly Nigeria for chilli pepper marketed fresh by informal channels from areas of high production of Oueme. The dry chilli pepper is exported actively to Niger, Togo, Senegal and Gabon. Ground chilli packed in small bags and transparent bottles is exposed with other condiments such as tomato (Solanum lycopersicum), onion (Allium cepa), other spices and salt on display in consumer markets and sold to housewives. After the tomato, chilli pepper is the most popular condiment in urban Benin for consumption. The round chilli pepper is often used fresh and whole in sauces, because of its very pleasant aroma. Photo 5 shows the different forms of use and direct consumption of chilli peppers in Benin.

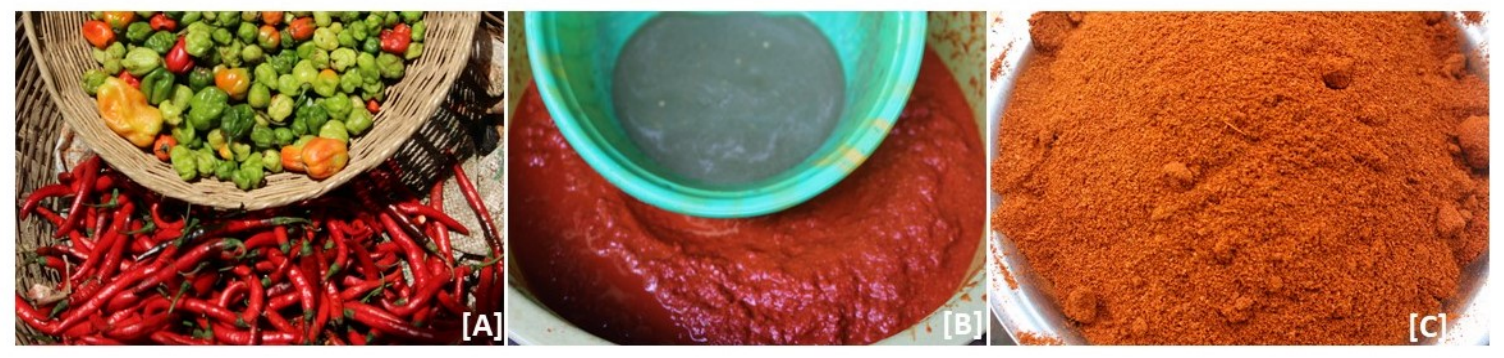

Photo 5: Forms of use and direct consumption of chilli pepper in Benin.

[A] Fresh chilli, [B] Ground in the wet state, [C] Chillipowder.

\section{CONSTRAINTS RELATED TO THE PRODUCTION OF CHILLI PEPPER}

Fifteen constraints affect chilli pepper production in Benin (Orobiyi, 2015). Among them, the most important are soil poverty, insect attack, low productivity, plant organ drop (leaves, flowers and fruits) and drought. Then come virosis, anthracnose, damping-off, low shelf life, harvesting difficulties, lack of quality seed, low market value, lack of market flow, sensitivity to excess soil moisture and root and crown rot. The importance of constraints also varies from one agro-ecological zone to another (Orobiyi, 2015). In the North, the most important constraints are: drought, soil poverty and low productivity. On the other hand, in Central Benin the main constraints enumerated by producers are the early fall of plant organs, low productivity and insect attack. In the south, insect attack, virosis, early plant drop, dampingoff and anthracnose are the main constraints. There are also abiotic constraints that usually result in a decrease in yield of chilli pepper plants (Goldberg, 2004). The causes of this decline are many. Table 4 and Table 5 present the constraints related to the production of 
chilli peppers in Benin and the variation in the importance and number of constraints related to the production of chilli peppers in the agroecological zones of Benin.

Table 4: Constraints related to chilli pepper production in Benin (Orobiyi, 2015)

\begin{tabular}{|c|c|c|c|}
\hline Constraints & $\begin{array}{l}\text { North } \\
\text { IMP (\%) }\end{array}$ & $\begin{array}{l}\text { Center } \\
\text { IMP (\%) }\end{array}$ & $\begin{array}{l}\text { South } \\
\text { IMP (\%) }\end{array}$ \\
\hline Drought & 17,79 & 8,42 & - \\
\hline Poverty of the soil & 17,06 & 11,78 & 6,83 \\
\hline Low productivity & 16,95 & 13,8 & 1,55 \\
\hline Falling organs & 12,11 & 14,81 & 13,67 \\
\hline Attack of insects & 11,68 & 12,46 & 25,81 \\
\hline Viroses & 6,74 & 7,41 & 15,84 \\
\hline Anthracnose (fruit rot) & 6,11 & 4,38 & 13,04 \\
\hline Lack of quality seeds & 2,21 & 2,36 & - \\
\hline Low shelf life & 1,89 & 6,06 & 8,39 \\
\hline Sowing & 1,47 & 2,36 & 13,32 \\
\hline Difficult harvest & 1,47 & 5,05 & - \\
\hline Sensitivity to excess moisture & 1,26 & 2,36 & 0,62 \\
\hline Low market value & 2,42 & 7,74 & - \\
\hline Root and crown rot & 0,84 & 1,01 & 0,93 \\
\hline \multicolumn{4}{|c|}{ NTV $:$ Total number of villages in which the constraint is quoted; } \\
\hline \multicolumn{4}{|c|}{ PCO: Main Constraints or number of villages in which the constraint is ranked among the top five; } \\
\hline \multicolumn{4}{|c|}{ CMAJ : Major Constraints or number of villages in which the constraint is ranked first; } \\
\hline IMP: Importance of a constraint & & & \\
\hline
\end{tabular}

Table 5: Variation in the importance and number of constraints related to chili production in agro-ecological zones (Orobiyi, 2015)

\begin{tabular}{|c|c|c|c|c|c|}
\hline Constraints & NTV & PCO & CMAJ & $\operatorname{IMP}(\%)$ & Rank \\
\hline Poverty of the soil & 106 & 88 & 25 & 14,08 & 1 \\
\hline Attack of insects & 112 & 81 & 22 & 13,83 & 2 \\
\hline Falling organs & 108 & 76 & 19 & 13,05 & 4 \\
\hline Drought & 88 & 78 & 28 & 12,48 & 5 \\
\hline Viroses & 62 & 57 & 18 & 8,81 & 6 \\
\hline Sowing & 32 & 24 & 10 & 4,24 & 8 \\
\hline Low shelf life & 41 & 13 & 9 & 4,05 & 9 \\
\hline Difficult harvest & 21 & 7 & 1 & 1,86 & 10 \\
\hline Lack of quality seeds & 21 & 6 & 1 & 1,80 & 11 \\
\hline Low market value & 21 & 2 & 0 & 1,48 & 12 \\
\hline \multicolumn{6}{|c|}{ PCO : Main Constraints or number of villages in which the constraint is ranked among the top five; } \\
\hline \multicolumn{6}{|c|}{ CMAJ : Major Constraints or number of villages in which the constraint is ranked first ; } \\
\hline IMP: Importance of a constraint. & & & & & \\
\hline
\end{tabular}

\section{$7 \quad$ FUNGAL DISEASES}

With regard to fungal diseases, different types of attack are distinguished: powdery mildew or leaf white, fruit anthracnose, leaf Sigatoka, velvet leaf spot, crown rot and semis melt (Photo 6). Of these six diseases, white or powdery mildew is the most widespread in tropical Africa. It is caused by the fungus Leveillula taurica which grows on the underside of the leaves causing chlorotic spots on the upper side, as in tomato. The development of the fungus is especially favoured by warm weather $\left(20^{\circ} \mathrm{C}\right.$ to $\left.28^{\circ} \mathrm{C}\right)$ and moderate drought $(50$ to $75 \%$ relative humidity). Infection is followed by necrosis and severe leaf drop, which increases the risk of sunburn and secondary fruit rots (Shankar et al., 2014). The 
viral complex is also a dangerous disease for the young plant (INRAB, 2009; Shankar et al., 2014). It consists of an attack of the plant by several types of virus. It is manifested by dwarfism: the plants are very little developed, the leaves are reduced, tense and discoloured. These plants carry very few flowers and fruits. Other fungal diseases occur mainly in the rainy season (Syukur et al., 2013). Anthracnose or fruit rot caused by Colletotrichum gloeosporioides and to a lesser extent by Colletotrichum capsici, which is a major problem in ripe fruit especially on wetlands, causing yield losses of up to $90 \%$. Leaf Sigatoka and velvet leaf spot caused by Cercospora capsici and Cercospora unamunoi respectively cause total defoliation of the plant (Sanogo 2003; Shankar et al., 2014). Downy mildew or crown rot caused by Phytophthora capsici affects all parts of the plant and is a very serious disease that greatly reduces the yield of growers (Jianhua et al., 1998; Shankar et al., 2014). Seedling or root rot is caused by Pythium spp and Fusarium spp. It causes no emergence of seedlings or sudden death of young plants (Declert, 1990). Post-harvest rots can be reduced by harvesting fruit in the dry season, reducing injury during handling and keeping it at cool temperatures (Shankar et al., 2014). Fruit washing can increase the rate of infected fruits, but losses can be reduced by adding chlorine to the wash water and drying the fruit.
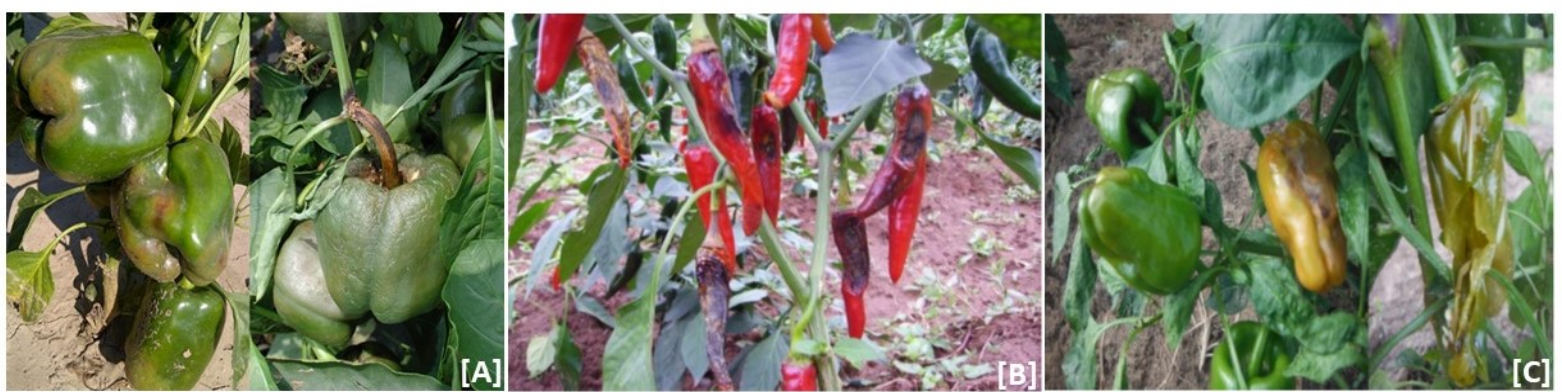

Photo 6: Some main diseases in the field of chilli pepper (Orobiyi, 2015)

[A] Bacterial wilt of chilli pepper fruits (Capsicum chinense variety), [B] Anthracnose of chillipepper fruits (Capsicum annuum variety),[C] Soft rot of chilli pepper fruits (Capsicum chinense variety).

\section{PROFILE AND MICROBIOLOGICAL QUALITY OF CHILLI PEPPER}

The presence of fungal contaminants on chilli peppers varieties is effective. Chilli pepper are likely to be contaminated with toxigenic fungi in fields, after harvest, during transport and during storage (FAO / WHO, 2017). Indeed, the cultivation techniques used could have an impact on the chilli pepper contamination in the field, especially in the humid lowlands. Also, improper storage or preservation methods used and the unsuitability of certain varieties for conservation would also lead to attacks by micro-organisms including fungi including molds of the genus Aspergillus, Penicillium, Fusarium and Alternaria (Zinedine, 2004; Nguyen, 2007; Debode et al., 2016). Molds are heterotrophic eukaryotic or multicellular multi-cellular fungi with a complex structure, endowed with the power of sporulation, developing on the surface of foodstuffs because of their aerobic nature (Meile, 2017). They are the most well-known contaminants in chilli peppers. Once on the chilli pepper, these micro-organisms alter the sanitary quality thus causing enormous economic losses (INRAB, 2009). Generally, contamination evolves after harvest, storage or storage based on a combination of intrinsic and extrinsic factors (Royer and Tap, 2004). There is no doubt that molds have a remarkable ability to adapt; a change in a technological process can lead to a quantitative and qualitative change in the mycoflora. Previous 
studies have confirmed the presence of fungal agents including Rhizoctonia solani, Colletotrichum sp. and Fusarium sp. strongly identified on chilli pepper (Fondio et al., 2015). A large number of mold species belonging mainly to the three very common genera Aspergillus, Penicillium, Fusarium (Zinedine, 2004; Nguyen, 2007; Debode et al., 2016), present in ambient air, soil, on agricultural crops are able, for example developing on certain substrates such as peanuts, spices, coffee, rice, cereals and cereal products, grapes, fruits, millet and sorghum to synthesize and excrete mycotoxins (Nguyen, 2007; Garba et al., 2014). Mycotoxins are products of the secondary metabolism of various molds that can be very toxic for humans and animals (Meile, 2017). It has been found that the same mycotoxin can be produced by various fungal species but not necessarily by all the strains belonging to the same species. Similarly, in some cases, the same species of fungus can produce several mycotoxins (Meile, 2017). They can grow on plants in the field or during storage. About 25\% of the world's food crops are attacked by mycotoxin-producing molds (FAO, 2008). Estimated total losses of food commodities due to mycotoxins are estimated at nearly 1000 million tonnes per year (FAO, 2008). The mode of mycotoxin production is complex: the same mold can produce different mycotoxins and the same mycotoxin can be produced by different molds. The factors triggering the production of mycotoxins are not yet well understood: a mold can be widely present on a commodity without secreting mycotoxins or little present and secrete mycotoxins in abundance. Productive mold can also disappear from the food, while mycotoxins, which are very stable, can persist even after heat treatment (Debode et al., 2016).
In terms of public health, the main mycotoxins considered are aflatoxins (B1, B2, G1 and G2), ochratoxin A (OTA), fumonisins (B1 and B2), certain trichothecenes (nivalenol-NIV, deoxynivalenol-DON, diacetoxyscirpelol-DAS, fusarenone $\mathrm{X}, \mathrm{T} 2$, HT2), patulin and zearalenone (Debode et al., 2016; Meile, 2017). The single or combined cytotoxic and genotoxic effects of these molecules have been demonstrated in several studies (Golli-Bennour, 2010; Houmairi and Hicham, 2015). The mechanism by which this toxin induces cancer is not fully understood and is the subject of debate (Manderville, 2005; Turesky, 2005; Pfohl-Leszkowicz and Manderville, 2007). Carcinogenic substances can act according to two types of mechanism: a genotoxic mechanism (capable of causing damage to DNA) or an epigenetic mechanism. The term epigenetic defines the transmissible and reversible modifications of gene expression that are not accompanied by changes in nucleotide sequences. Taking into account the effects of cumulation and synergy of these molecules in the body, it is essential that preventive means such as the choice of chilli pepper of good quality to purchase and their good conservation under conditions of temperature and humidity moisture are a general strategy for consumer protection (Houmairi and Hicham, 2015). Good Agricultural Practices (GAP), Good Manufacturing Practices (GMP) and Good Storage Practices (GEPs) could help minimize mycotoxin contamination during all stages of chilli pepper production from primary production to for use by the consumer. It is advisable to apply GAP, GMP and BEP for pre-harvest, during processing and storage respectively (FAO / WHO, 2017). The table 6 presents the risks of toxicity caused by the main mycotoxins. 
6: Risks of toxicity caused by the main mycotoxins (Meilé, 2017)

\begin{tabular}{|c|c|c|}
\hline Toxin & Effets & Cellular and molecular mechanisms of action \\
\hline \multirow[t]{4}{*}{ Aflatoxin B1 + M1 } & - Hepatotoxicity & - DNA adduct formation \\
\hline & - Genotoxicity & - Lipid peroxidation \\
\hline & - Carcinogenicity & - Bioactivation by cytochromes P450 \\
\hline & - Immunomodulation & - Conjugation with Glutathione transferases \\
\hline \multirow[t]{3}{*}{ Ochratoxin A } & - Nephrotoxicity & - Impact on protein synthesis \\
\hline & - Genotoxicity & - Inhibition of ATP production \\
\hline & - Immunomodulation & - Detoxification by peptidases \\
\hline \multirow[t]{2}{*}{ Patulin } & - Neurotoxicity & - Indirect inhibition of enzymes \\
\hline & - In vitro mutagenesis & \\
\hline \multirow[t]{3}{*}{ Trichothecenes (groups A and B) } & - Hematotoxicity & - Induction of apoptosis on hematopoietic progenitor and immune cells \\
\hline & - Immunomodulation & - Impact on protein synthesis \\
\hline & - Skin toxicity & - Alteration of immunoglobulins \\
\hline \multirow[t]{3}{*}{ Zearalenone } & - Fertility and Reproduction & - Estrogen receptor binding \\
\hline & & - Bioactivation by dehydrogenases \\
\hline & & - Conjugation with glucuronyltransferase \\
\hline \multirow[t]{3}{*}{ Fumonisin B1 } & - Central nervous system damage & - Inhibition of ceramide synthesis \\
\hline & - Hepatotoxicity & - Alteration of the sphinganine / sphingosine ratio \\
\hline & - Genotoxicity & - Alteration of the cell cycle \\
\hline
\end{tabular}

\section{CONCLUSION}

This bibliographic review has carried out a detailed diagnosis of the current state of the chilli pepper industry in Benin, from the installation of the crop to the transformation of production with the essential aim of listing all the failures techniques hindering the opening of the sector on its socio-economic environment and to propose recommendations for improvements in the sanitary quality of this crop. The chilli pepper is today, the most consumed spice, entering almost all food and especially in all local dishes in Benin. In general, the agricultural constraints linked to the technical cultivation routes favor the contamination of the plant at different stages by diseases caused by the different microorganisms including bacteria, viruses and especially fungi. Based on all the intrinsic and extrinsic factors, this contamination continues after harvesting until the spice is placed on the market, sometimes passing through the storage and preservation stage. While taking into account the achievements already made by research in this area, it is in the perspective of removing the main constraints that undermine the chilli pepper sector and promote technical crop routes and standardized storage and storage methods allowing obtaining good quality chilli pepper chilli pepper and minimizing post-harvest economic losses that this work has been initiated. This review also presents the byproducts resulting from the transformation of the chilli pepper that must be exploited to the best advantage in order to develop the chilli pepper sector in Benin and constitutes upstream a part of the future works which will concern the project entitled: Technical itineraries, susceptibility to mold and determination of mycotoxins in the chilli pepper production chain (Capsicum spp.) in Benin.

\section{ACKNOWLEDGMENT}

We thank the Campus France through the Service Cooperation and Cultural Action (SCAC) of the Embassy of France for the financial support provided for this research.

\section{REFERENCES}

Adetula AO. and Olakojo SA: 2006. Genetic Characterization and Evaluation of Some Pepper Accessions Capsicum frutescens (L.): The Nigerian 'Shombo' Collections.
American-Eurasian Journal of Agricultural \& Environmental Sciences 1: 273-281.

Adjatin A, Dansi A, Eze CS, Assogba P, DossouAminon I, Akpagana K, Akogninou A. 
and Sanni A: 2012. Ethnobotanical investigation and diversity of Gbolo (Crassocephalum rubens (Juss. ex Jacq.) S. Moore and Crassocephalum crepidioides (Benth.) S. Moore), a traditional leafy vegetable under domestication in Benin. Genetic Resources and Crop Evolution 10: 115.

Adoukonou-Sagbadja H, Dansi A, Vodouhe R. and Akpagana K: 2006. Indigenous knowledge and traditional conservation of Fonio millet (Digitaria exilis Stapf, Digitaria iburua Stapf) in Togo. International Journal of Biodiversity and Conservation 15: 2379-2395.

Akoègninou $A$, van der Burg WJ. and van der Maesen LJG: 2006. Flore analytique de Bénin. Backhuys Publishers, Leiden, Cotonou, République du Bénin. 1034 pp.

Assogba-Komlan F, Mensah A, Azagba J. and Ahlè V: 2007. Evaluation de nouvelles variétés de tomate d'hivernage et de piment contre l'anthracnose. Rapport d'activité PCM /Institut National des Recherches Agricoles du Bénin. 29pp.

Assogba-Komlan F, Sikirou R, Sodjinou E. and Mensah A: 2009. Production durable du piment au Bénin. MAEP/ Institut National des Recherches Agricoles du Bénin. Référence technico-économique de la production agricole, République du Bénin. 48pp.

Bae H, Jayaprakasha GK, Jifon J. and Patil BS: 2012. Variation of antioxidant activity and the levels of bioactive compounds in lipophilic and hydrophilic extracts from hot pepper (Capsicum spp.) cultivars. Food Chemistry 134: 1912-1918.

Bortolotti M, Coccia G, Grossi G. and Miglioli M: 2002. The treatment of functional dyspepsia with red pepper. Alimentary Pharmacology and Therapeutics 16: 10751082.

Boland PW. and Votava EJ: 2000. Peppers: vegetable and spice capsicums. The Journal of Agricultural Science 136: 171-175.

Chaine-Dogimont C: 1993. Etude génétique de trois systèmes de résistance par hypersensibilité ou séquestration aux trois virus principaux infectant le piment
(Capsicum annuum L.). Thèse de doctorat, INA-PG. Paris, France. 194 pp.

Costa LV, Lopes R, Lopes MTG, de Figueiredo AF, Barros WS. and Alves SRM: 2009. Cross compatibility of domesticated hot pepper and cultivated sweet pepper. Crop Breeding and Applied Biotechnology 9: 37-44.

Dansi A, Adoukonou-Sagbadja H. and Vodouhe R: 2010. Diversity, conservation and related wild species of Fonio millet (Digitaria spp) in the northwest of Benin. Genetic Resources and Crop Evolution 57: 827839.

Debode F, Lateur M, Van Damme J. and CRAW: 2016. Les mycotoxines. Itinéraires BIO. Dossier spécial: Conservation des fruits et légumes 30: 30-32.

Declert C: 1990. Manuel de phytopathologie maraîchère tropicale: cultures de Côte d'Ivoire. Coll. "Didactiques ». Editions de I'ORSTOM, Institut Français de Recherché Scientifique pour le Développement en Coopération, Paris, France. 333 pp.

Dossou-Aminon I, Loko YL, Adjatin A, Ewédjè EBK, Dansi A, Rakshit S, Cissé N, Patil JV, Agbangla C, Sanni A, Akoègninou A. and Akpagana K: 2015. Genetic divergence in northern Benin sorghum (Sorghum bicolor L Moench) landraces as revealed by agromorphological traits and selection of candidate genotypes. Scientific World Journal, Volume 2015, Article ID 916476, 10 pages.

FAO: 2018. FAOSTAT Database. Food and Agriculture Organization, Roma, Italy. Available online at URL: www.fao.org.

FAO/OMS: 2017. COMMISSION DU CODEX ALIMENTARUS. Demande d'observations à l'étape 3 sur l'avantprojet de code d'usages pour la prévention et la réduction de la contamination des épices par les mycotoxines. CL 2017/28-CF, Février 2017: 1-14.

FAO: 2016. FAOSTAT Database. Food and Agriculture Organization, Roma, Italy. Available online at URL: www.fao.org.

FAO/WHO: 2008. Human Vitamin and Mineral

Requirements. Report of a Joint 
FAO/WHO Expert Consultation: Food and Agriculture Organization/World Health Organization, 2nd Edition, Bangkok, Thailand. 20pp.

FAO/OMS : 2007. Programme mixte FAO/OMS sur les normes alimentaires, Commission du Codex Alimentarius. Céréales, légumes secs, légumineuses et matières protéiques végétales, 1 ère édition, Rome, Italie. 128pp.

Fondio L, N'zi JC. and Kobenan K: 2015. Comportement agronomique et sanitaire de nouvelles lignées de piment (Capsicum sp) dans le Sud de la Côte d'Ivoire. Journal of Applied Biosciences 92: 8594 - 8609.

Garba K, Adeoti K, Hodonou A, Tidjani A, Hounhouigan J. and Toukourou F: 2014. Study of Sanitary of Groundnut Oil and Peanut Cakes from Agonlin Plateau: Identification of Critical Control Points during Groundnut Craft Transformation. Microbiologie Hygiène Alimentaire 75: 17-21.

Gbaguidi AA, Assogba P, Dansi M, Yedomonhan H. and Dansi A: 2015. Caractérisation agromorphologique des variétés de niébé cultivées au Bénin. International Journal of Biological and Chemical Sciences 9: 1050-1066.

Gbaguidi AA, Dansi A, Loko LY, Dansi M. and Sanni A: 2013. Diversity and agronomic performances of the cowpea (Vigna unguiculata $W$ alp) landraces in Southern Benin. International Research Journal of Agricultural Science and Soil Science 4: 936949.

Goldberg PN: 2004. Chile Pepper Disorders Caused by Environmental Stress. Department of Agriculture cooperating. Guide H249. 2 pp.

Gomez-Guillamon ML. and Cuartero J: 1987. Inheritance of vegetative characters in pepper (Capsicum annuum L.). Agronomie EDP Sciences 7: 271-277.

Golli-Bennour E, Kouidhi B, Bouslimi A, AbidEssefi S, Hassen W. and Bacha H: 2010. Journal of biochemical and molecular toxicology 24: 42-50.

Grubben GJH. and El Tahir IM: 2004. Capsicum annum L. In: Grubben GJH. \& Denton OA. (eds.). PROTA 2: Vegetables/Légumes. [CD-Rom].
PROTA, Wageningen, the Netherlands. $19 \mathrm{pp}$.

Guerrero M: 2000. Effets de la capsaïcine sur le métabolisme énergétique et la prise alimentaire chez des personnes ayant perdu du poids. Mémoire du grade de maitre ès sciences (M.Sc.). Québec, Canada. 65pp.

Hakmaoui A, Zaki N, Baye Y. and Ouatamane A: 2013. Techniques de production du piment rouge (niora) au périmètre irrigué de tadla. Transfert de Technologie en Agriculture, Tadla-Azila, Maroc. 198: 1-6.

INRAB: 2009. Référentiel technico-économique de la production agricole. Production durable du piment au bénin. Institut National des Recherches Agricoles du Bénin, Abomey-Calavi, République du Bénin.47pp.

Jin R, Pan J, Xie H, Zhou B. and Xia X: 2009. Separation and Quantitative Analysis of Capsaicinoids in Chilli Peppers by Reversed-Phase Argentation LC. Chromatographia Journal 70: 1011-1015.

Kombo GR, Dansi A, Loko LY, Orkwor GC, Vodouhè R, Assogba P. and Magema JM: 2012. Diversity of cassava (Manihot esculenta Crantz) cultivars and its management in the department of Bouenza in the Republic of Congo. Journal of Plant Genetics and Crop Evolution 59: 1789-1803.

Kumari KA, Kumar KNR. and Rao CHN: 2014. Adverse effects of chemical fertilizers and pesticides on human health and environment. Journal of Chemical and Pharmacentical Sciences 3: 150-151.

Labat JJ: 1996. LA CAPASAICINE INTRAVESICALE. Constat, Bordeaux, France. $11 \mathrm{pp}$.

MAEP: 2007. Etude sur le sous-secteur du maraîchage au Sud-Bénin. Rapport final, Cotonou, République du Bénin.8pp.

Manderville RA: 2005. A case for the genotoxicity of ochratoxin A by bioactivation and covalent DNA adduction. Chemical Research in Toxicology Journal 18: 1091-1097.

Meile JC: 2017. Risques et enjeux associés à la présence de mycotoxines sur les cultures et aliments de l'Océan Indien. UMR 
Qualisud - CIRAD Réunion, Journées Qualireg, Montpellier, France. 24pp.

Nguyen MT: 2007. Identification des espèces de moisissures potentiellement productrices de mycotoxine dans le riz commercialisé dans cinq provinces de la région centrale de Vietman-Etude des conditions pouvant induire la production de mycotoxines. Thèse de doctorat, Toulouse, France. 147pp.

Orobiyi A: 2015. Etude ethnobotanique, evaluation participative et caracterisations agromorphologique et biochimique du piment (Capsicum annuum L.) au Bénin. Thèse de doctorat. Abomey-Calavi, République du Bénin. 119pp.

Pfohl-Leszkowicz, A. and Manderville RA: 2007. Ochratoxin A: anoverview on toxicity and carcinogenicity in animals and humans. Molecular Nutrition \& Food Research 51: 6199.

PNUD-BENIN-PANA 1: 2015. Renforcement des capacités des maraîchers des communes de Adjohoun, de Bopa, et de Ouaké sur l'amélioration des techniques de production et de réduction des impacts des risques climatiques sur la culture du piment, Abomey-Calavi, République du Bénin. 35pp.

Royer G. and TAP J: 2004. Les mycotoxines. Université Paris XII Année 2003/2004 Institut Universitaire Professionnalisé. Salon International de l'Alimentation (SIAL), Paris, France. 7pp.

Sanogo S: 2003. Chile pepper and the threat of wilt diseases. Online. Plant Health Progress. http://www.plantmanagementnetwork.or $\mathrm{g} / \mathrm{pub} / \mathrm{php} / \mathrm{review} / 2003 /$ chile/

Shankar R, Seema H. and Raj B: 2014. A practical guide to identification and control of pepper diseases. South End Road, 1st Floor, Basavangudi. Tropica Seeds Private Limited 54:1-61.

Syukur M, Sujiprihati S. and Koswara J: 2013. Genetic analysis for resistance to anthracnose caused by Colletotrichum acutatum in chilli pepper (Capsicum annuиm L.) using diallel crosses. $S A B R A O$ Journal of Breeding and Genetics 45: 400-408.
Tilahun S, Paramaguru P. and Rajamani K: 2013. Capsaicin and ascorbic acid variability in chilli and paprika cultivars as revealed by HPLC analysis. Journal of Plant Breeding and Genetics 01: 85-89.

Tundis R, Menichini F, Bonesi M, Conforti F, Statti G, Menichini F. and Loizzo MR: 2013. Antioxidant and hypoglycaemic activities and their relationship to phytochemicals in Capsicum annuum cultivars during fruit development. Food Science and Technology 53: 370-377.

Turesky RJ: 2005. Perspective: ochratoxin A is not a genotoxic carcinogen. Chemical Research in Toxicology Journal 18: 1082-1090.

Zinedine A: 2004. Détermination des mycotoxines dans les aliments et étude de la réduction des aflatoxines par les bactéries lactiques isolées des ferments panaires traditionnels. Thèse de doctorat, Maroc. 120pp. 